\title{
Lead Poisoning in Gurkha Soldiers in Hong Kong
}

\author{
J. G. P. POWER,* D.P.H., D.I.H., D.T.M.\&H.; R. M. BARNES, † M.R.C.P.ED., M.C.PATH., D.T.M.\&H. \\ W. N. C. NASH, $\ddagger$ M.B., B.CH. ; J. D. ROBINSON,§ H.N.C., A.I.M.L.T.
}

British Medical fournal, 1969, 3, 336-337

\begin{abstract}
Cummary : Investigation of an outbreak of lead-poison$\checkmark$ ing in 121 Gurkha soldiers showed that this was due to the contamination of chilli powder (cayenne pepper), a constituent of curry powder, with lead chromate. Comprehensive systems of food sampling are needed in developing communities.
\end{abstract}

\section{Introduction}

Lead-poisoning due to the ingestion of contaminated food or drink is less common than industrial intoxication resulting from inhaled lead dust or fume. Children have been poisoned through eating lead in paint, putty, or soil (Barltrop, 1968), whereas plumbism in adults is usually associated with drinking highly contaminated beer, cider, or water (Monier-Williams, 1949 ; Ministry of Food, 1954). Lead-contaminated food was the cause of the outbreak of plumbism in 121 Gurkha soldiers described in this paper.

\section{History of Outbreak}

In the week beginning 24 March 1968 four Gurkha soldiers reported sick with epigastric pain, nausea, and constipation, and were treated for gastritis. More soldiers presented the same symptoms during the following week, but exquisite tenderness of the recti abdominis and other muscles led to suspicion of "epidemic myalgia." It was observed that only the single men of the unit were affected.

All patients were admitted to the military hospital, where the discovery of anaemia and basophilic stippling of red cells suggested heavy metal poisoning. The cookhouse was closed on 22 April and resulted in a significant decrease in new cases (see Chart). Intensive investigations in the single men's cookhouse showed that the "ghee" (clarified butterfat) used in the cooking process was contaminated with lead. After the removal of the contaminated ghee the cookhouse was reopened on 14 May.

Nevertheless, during the ensuing week the appearance of new cases as well as the reappearance of several old ones indicated that lead-poisoning was still occurring. Further analysis revealed chilli powder contaminated with lead. After removal of this on 17 June only two further cases of acute lead-poisoning occurred. The Chart shows three distinct phases in the outbreak with new cases presenting in two peak periods separated by a quiescent one.

Of the 75 patients with symptoms 63 complained of constant epigastric pain but only 20 had classical "lead colic." Complaints of nausea, constipation, and headache were common, whereas arthralgia, mainly of knees and elbows, was an occasional occurrence. Blue lines on the gum margins were seen

* Lieutenant-Colonel, Royal Army Medical Corps ; Consultant in Army Health, H.Q. Land Forces, Hong Kong.

† Lieutenant-Colonel, Royal Army Medical Corps; Consultant Pathologist, British Military Hospital, Hong Kong.

₹ Captain, Royal Army Medical Corps ; Regimental Medical Officer, Gun Club Barracks, Hong Kong.

$\checkmark$ Experimental Officer in Biochemistry, British Military Hospital, Hong Kong. in about $19 \%$ of patients. An unexpected finding was bilateral limitation of lateral gaze in $60 \%$ of patients. Anaemia was the most striking feature, 110 of the 121 patients showing haemoglobin levels of less than $11.4 \mathrm{~g} . / 100 \mathrm{ml}$. of blood, of whom 79 had less than $10.1 \mathrm{~g} . / 100 \mathrm{ml}$. Basophilic stippling of red cells was seen in $51 \%$ of all cases.

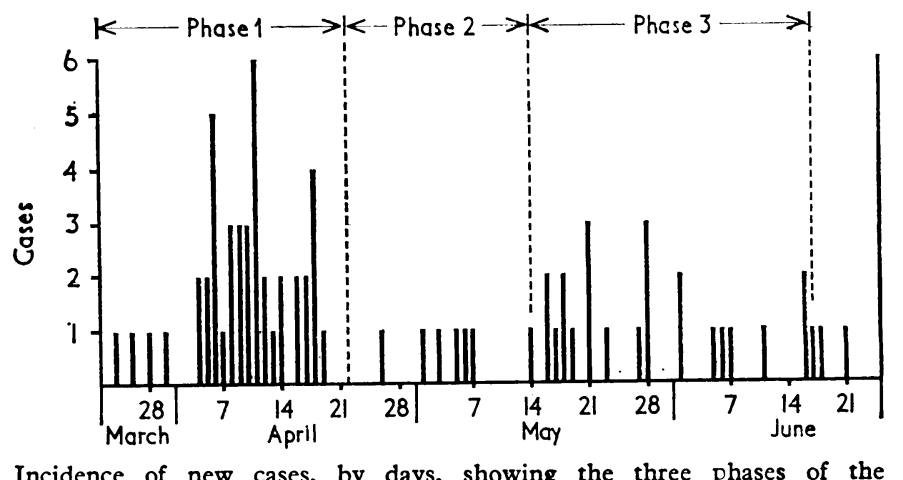

Incidence of new cases, by days, sho

Urinary coproporphyrin . levels exceeding $200 \mu \mathrm{g} . / 1$. were found in $86 \%$ of the patients. Urinary lead excretion rates were investigated in 58 patients and showed an average figure of $455 \mu \mathrm{g}$. in 24 hours (range 158 to $610 \mu \mathrm{g}$.).

Forty married Gurkha soldiers from the same unit living and eating with their families in married quarters in the same barracks were investigated. Two of them had haemoglobin levels below $14.4 \mathrm{~g} . / 100 \mathrm{ml}$., basophilic stippling, and urinary coproporphyrin levels exceeding $200 \mu \mathrm{g}$. $/ 1$. In fact one of these men was a cook who had worked in the contaminated cookhouse and the other performed special duties which necessitated living with the single men.

Finally large numbers of soldiers from the several other Gurkha units in Hong Kong were investigated but no evidence of lead intoxication was found.

\section{Epidemiological Investigations}

The affected soldiers were vehicle drivers, vehicle maintenance men, or office clerks. No source of lead was discovered in the work environment. Sampling of the recently painted internal walls and the atmosphere in the barrack room gave negative results for lead. Negative results for excess heavy metal contamination were obtained in investigations on alcoholic and non-alcoholic beverages in the cookhouse and canteen and the water supply. Finally the analysis of large numbers of samples of cooked and uncooked foodstuffs showed a source of lead in the ghee.

\section{Sources of Lead}

The staple diet of the Gurkha soldiers is a twice-daily meal of boiled rice, vegetables, and curried meat or fish. A sample of cooked chicken curry had lead in excess and this ultimately led to investigation of the ghee used to fry the meat or fish 
before the addition of curry powder. Samples of ghee which had been reused several times in the cooking process were taken from a metal container in the cookhouse and on analysis were found to contain 50 parts per million of lead. Unused ghee had a lead content of 0.6 p.p.m. The ghee container was made from a lead-free metal alloy and was electrically welded; therefore it was concluded that the source of lead was the reused ghee itself, becaused at this time all cooking equipmentthat is, pots, pans, and utensils-had been checked and eliminated as possible sources of lead.

Lead estimations of the morning and evening meal were performed over a six-day period. Normal lead ingestion is about $300 \mu \mathrm{g}$./day (Monier-Williams, 1949) and of the samples investigated only those dishes which were curried contained significantly high lead levels (Table I).

TABlE I.-Lead Content of One Soldier's Rations for Six Days Before Removal of Contaminated Chilli Powder

\begin{tabular}{|c|c|c|c|c|c|c|c|}
\hline \multicolumn{6}{|c|}{ Foodstuff } & \multirow{2}{*}{$\begin{array}{c}\begin{array}{c}\text { Total } \\
\text { Wet Weight } \\
\text { (g.) }\end{array} \\
3,870 \\
970 \\
550 \\
1,980 \\
895 \\
450 \\
105 \\
116 \\
4,000\end{array}$} & \multirow{2}{*}{$\begin{array}{r}\begin{array}{r}\text { Total } \\
\text { Lead } \\
(\mu \mathrm{g} .)\end{array} \\
200 \\
34,000 \\
10,800 \\
6,650 \\
9,185 \\
6,875 \\
31 \\
12 \\
200\end{array}$} \\
\hline $\begin{array}{l}\text { Rice, boiled } \\
\text { Meat, curried } \\
\text { Fish, curried } \\
\text { Dahl, spiced } \\
\text { Vegetable, cu } \\
\text { Egg and vege } \\
\text { Fruit, tinned } \\
\text { Fruit, fresh } \\
\text { Tea } \quad .\end{array}$ & $\begin{array}{l}\because \\
\therefore \\
\text { ed } \\
\text { le, c } \\
\cdots \\
\therefore\end{array}$ & $\begin{array}{l}\because \\
\because \\
\because \\
\ddot{r e d} \\
\therefore \\
\therefore\end{array}$ & $\begin{array}{l}\ldots \\
\because \\
\because \\
\because \\
\because \\
\cdots\end{array}$ & $\begin{array}{l}\ldots \\
\because \\
\cdots \\
\cdots \\
\cdots \\
\cdots \\
\cdots\end{array}$ & $\begin{array}{l}\ldots \\
\because \\
\cdots \\
\cdots \\
\cdots \\
\cdots\end{array}$ & & \\
\hline Total .. & . & . & $\ldots$ & $\ldots$ & $\ldots$ & 12,936 & 67,953 \\
\hline \multicolumn{5}{|c|}{ Total lead ingested from food per day } &.$:$ & & $11,325 \cdot 5$ \\
\hline
\end{tabular}

The various spices used to prepare the curry powder were analysed (Table II) and the sample of chilli powder showed the astonishingly high lead level of 10,800 p.p.m. It is thought that whole chilli pods, imported from mainland China, were pulverized in one or both of the two grinding machines in a small grinding factory. Investigations into grinding machines in various food processing establishments in Hong Kong revealed that they are made from an iron-zinc alloy, containing no lead. Clearly the grinding machines themselves, which are lead free, did not cause contamination. Deliberate adulteration may have been practised to improve the colour or to increase the weight of chilli powder. Continuing investigations have so far failed to show the method by which contamination occurred.

TABle II.-Lead Content of Spices in Curry Powder

\begin{tabular}{|c|c|c|c|c|c|c|}
\hline \multicolumn{6}{|c|}{ Spice } & $\begin{array}{l}\text { Total Lead } \\
\text { (parts per million) }\end{array}$ \\
\hline $\begin{array}{lcc}\text { Till seed ... } & \ldots \\
\text { Black pepper, powdered } \\
\text { Cinnamon } & \ldots & \ldots \\
\text { Turmeric } & \ldots & \\
\text { Condiment, powdered } & \ldots \\
\text { Chillis, powdered } & \ldots\end{array}$ & $\begin{array}{l}\because \\
\because \\
\cdots \\
\cdots\end{array}$ & $\begin{array}{l}\because \\
\because \\
\cdots \\
\cdots\end{array}$ & $\begin{array}{l}\because \\
\because \\
\because \\
\cdots\end{array}$ & $\begin{array}{l}\because \\
\because \\
\because\end{array}$ & $\begin{array}{l}\because \\
\because \\
\because\end{array}$ & $\begin{array}{r}1 \cdot 0 \\
2 \cdot 4 \\
20 \cdot 0 \\
16 \cdot 0 \\
8 \cdot 0 \\
10,800 \cdot 0\end{array}$ \\
\hline Total & . & $\cdots$ & $\cdots$ & $\cdots$ & $\cdots$ & $10,847 \cdot 4$ \\
\hline
\end{tabular}

\section{Discussion}

The history of lead-poisoning by ingestion goes back to the Roman Empire at least. Gilfillan (1965) stated that the introduction of Greek winemaking and cooking was a major factor in the destruction of the Roman civilization. The dangers of using leaden containers and cooking equipment are well known today, and lead levels in food and drink are controlled by legislation so that massive food-poisoning on this scale is most unlikely to be repeated.

Deliberate adulteration of curry powder with lead salts to enhance its colour was commonly practised in the nineteenth century (Hassall, 1876). Between 1800 and 1850 the flagrant adulteration of foodstuffs generally was rife in England until Accum ruthlessly exposed the character and extent of this food faking. In 1851 the Lancet established a so-called "Scientific Detective Police" to investigate and expose the fraudulent adulteration of food by grocers and other tradesmen (Drummond and Wilbraham, 1957).

In recent times the Ministry of Food (1954) recommended a maximum permissible level of 10 p.p.m. of lead in curry powder, but under the Lead in Food Regulations, 1961 (Ministry of Agriculture, 1961) 20 p.p.m. was accepted finally for ground spices. Similar levels are applied in most other countries in the world. The Food Standards Committee reported (Ministry of Food, 1948) that some Indian merchants sought to improve the colour of turmeric, a constituent of curry powder, by dressing it with lead chromate. Paragraph 23 of the report also stated that "the grinding process to which the spices are subjected may be another source of lead contamination, but that traces attributable to this source are relatively rare."

The only other recorded instance of contamination of curry powder in military practice was that described by Caldwell and Barnes (1957) in Singapore. However, the contaminant was not lead but a toxic convulsant known as "star anise," the fruit of Illicium religiosum, which had been added to the curry powder as a flavouring agent.

Prevention of similar large-scale incidents in future depends on closer supervision of food processing establishments, particularly in developing countries. More comprehensive sampling of foodstuffs purchased in bulk may be necessary. This measure has been instituted by the Army in Hong Kong, and food stocks are also held back until the food analyst declares all samples free of lead and other contaminants.

We wish to record our appreciation for the assistance provided by the following: Major-General R. G. J. Morrison, lately Director of Medicine and Consulting Physician to the Army; the Director of Medical and Health Services, Hong Kong, and his staff, with particular reference to the Government Chemist, Dr. E. G. N. Greaves and also Dr. G. I. Forbes; the Director of the Urban Services and his staff, particularly Dr. T. Taylor; the physicians and the laboratory staff of the British Military Hospital, particularly Sergeant Young, R.A.M.C. ; and, finally, the Army Health Inspectors Team, led by W.O. II Bowen, R.A.M.C.

\section{REFERENCES}

Barltrop, D. (1968). Postgraduate Medical fournal, 44, 537.

Caldwell, A. F., and Barnes, J. (1957). Fournal of the Royal Army Medical Corps, 103, 91.

Drummond, J. C., and Wilbraham, A. (1957). The Englishman's Food. Cape, London.

Gilfillan, S. C. (1965). Fournal of Occupational Medicine, 7, 53.

Hassall, A. H. (1876). Food, Its Adulteration and Methods for its Detection. Longmans, Green, London.

Ministry of Food (1948). Food Standards Committee Report on Curry Powder. London, H.M.S.O.

Ministry of Food (1954). Food Standards Committee Report on Lead. London, H.M.S.O.

Ministry of Agriculture, Fisheries, and Food (1961). Lead in Food Regulations, Circular 9/61. London, H.M.S.O.

Monier-Williams, G. W. (1949). Trace Elements in Food. Chapman 